\title{
Baanzoekduren van hbo'ers onder de loep
}

Citation for published version (APA):

Borghans, L., \& Willems, E. (1994). Baanzoekduren van hbo'ers onder de loep. Researchcentrum voor Onderwijs en Arbeidsmarkt, Faculteit der Economische Wetenschappen. ROA Research Memoranda No. 4 https://doi.org/10.26481/umaror.1994004

Document status and date:

Published: 01/01/1994

DOI:

10.26481/umaror.1994004

Document Version:

Publisher's PDF, also known as Version of record

\section{Please check the document version of this publication:}

- A submitted manuscript is the version of the article upon submission and before peer-review. There can be important differences between the submitted version and the official published version of record.

People interested in the research are advised to contact the author for the final version of the publication, or visit the DOI to the publisher's website.

- The final author version and the galley proof are versions of the publication after peer review.

- The final published version features the final layout of the paper including the volume, issue and page numbers.

Link to publication

\footnotetext{
General rights rights.

- You may freely distribute the URL identifying the publication in the public portal. please follow below link for the End User Agreement:

www.umlib.nl/taverne-license

Take down policy

If you believe that this document breaches copyright please contact us at:

repository@maastrichtuniversity.nl

providing details and we will investigate your claim.
}

Copyright and moral rights for the publications made accessible in the public portal are retained by the authors and/or other copyright owners and it is a condition of accessing publications that users recognise and abide by the legal requirements associated with these

- Users may download and print one copy of any publication from the public portal for the purpose of private study or research.

- You may not further distribute the material or use it for any profit-making activity or commercial gain

If the publication is distributed under the terms of Article $25 \mathrm{fa}$ of the Dutch Copyright Act, indicated by the "Taverne" license above, 


\section{Baanzoekduren van HBO'ers onder de loep}

L. Borghans en E.J.T.A. Willems

ROA-RM-1994/4

Researchcentrum voor Onderwijs en Arbeidsmarkt

Faculteit der Economische Wetenschappen

Rijksuniversiteit Limburg

Maastricht, december 1994 
CIP-GEGEVENS KONINKLIJKE BIBLIOTHEEK, DEN HAAG

Borghans, L.

Baanzoekduren van HBO'ers onder de loep / L. Borghans en E.J.T.A. Willems. - Maastricht: Researchcentrum voor Onderwijs en Arbeidsmarkt, Faculteit der Economische Wetenschappen, Rijksuniversiteit Limburg. - (ROA-RM-1994/4)

Met lit. opg.

ISBN 90-5321-146-2

Trefw.: hoger beroepsonderwijs en arbeidsmarkt. 
Inhoudsopgave

Bladzijde

Samenvatting i

1 Inleiding 1

2 Bepaling van de baanzoekduur $\quad 2$

3 Resultaten $\quad 5$

4 De baanzoekduur van academici $\quad 7$

5 Besluit . $\quad 9$

$\begin{array}{ll}\text { Literatuur } & 9\end{array}$ 


\section{Samenvatting}

Sinds enkele jaren wordt op basis van gegevens uit de Enquête Beroepsbevolking een schatting gemaakt van de gemiddelde baanzoekduur van schoolverlaters. Deze schattingen trekken vanwege hun hoogte steeds de aandacht van de pers. Volgens recente berichten bedraagt de gemiddelde baanzoekduur voor schoolverlaters 9 maanden. Pas afgestudeerde academici zouden zelfs een zoektijd van gemiddeld 20 maanden in het vooruitzicht hebben. In dit research memorandum worden enige kanttekeningen bij deze cijfers geplaatst. Op basis van gegevens die specifiek bedoeld zijn voor het in kaart brengen van het intredeproces van schoolverlaters op de arbeidsmarkt, kan worden geconcludeerd dat het wel meevalt met de gemiddelde zoekduur tussen schoolverlaten en de eerste relevante baan. Een voorzichtige berekening laat zien dat de geschatte baanzoekduren, vanwege meetproblemen in het gebruikte databestand, een factor 3 te hoog zijn. Voor academici is deze overschatting van de zoekduur waarschijnlijk nog veel groter.

De auteurs danken Hans Heijke en Rolf van der Velden voor hun commentaar op de concept-versie van dit paper en Ron Dekker voor zijn hulp bij het bewerken van de HBO-Monitor-gegevens. 


\section{Inleiding}

De werkloosheid is in Nederland in 1993 fors opgelopen. Pas sinds enkele maanden constateert het Centraal Bureau voor de Statistiek (CBS) weer een geringe daling van het aantal werklozen. Het spreekt voor zich dat de nieuwkomers op de arbeidsmarkt in belangrijke mate het slachtoffer worden van een achterblijvende of zelfs teruglopende werkgelegenheid. Ook hoger opgeleiden ontkomen niet meer aan het gevaar van werkloosheid. Soms wordt zelfs beweerd dat de universiteit en hogeschool geen verbetering van de arbeidsmarktkansen meer betekenen, omdat ze alleen nog voor werkloosheid op zouden leiden. Dit maakt het interessant om juist de werkloosheid onder schoolverlaters nader te belichten.

Uit recentelijk door de Stichting voor Economisch Onderzoek der Universiteit van Amsterdam (SEO) in samenwerking met het CBS uitgevoerd onderzoek blijkt dat de schoolverlaters in het afgelopen jaar gemiddeld genomen ongeveer 9 maanden naar hun eerste ( $\min$ of meer volwaardige) baan hebben gezocht ${ }^{1}$. Voor academici bedraagt de gemiddelde baanzoekduur volgens dit onderzoek maar liefst 20 maanden. Deze cijfers over de gemiddelde baanzoekduur betekenen nogal wat voor de mate waarin de uitstroom uit het onderwijs aansluit op de behoeften op de arbeidsmarkt. Het is daarom weinig verrassend dat hieraan in de media de nodige aandacht is besteed ${ }^{2}$. Ook de recente en aankomende schoolverlaters zullen verontrust van deze cijfers kennis hebben genomen. Een baanzoekperiode van 9 maanden is immers geen prettig vooruitzicht.

Ondanks de slechte situatie op de arbeidsmarkt roept de gemiddeld erg lange zoekperiode twijfels op. Een gemiddelde zoektijd van 9 maanden betekent immers dat tegenover iedereen die direct na schoolverlaten of afstuderen een baan vindt, er iemand moet staan die pas na 1,5 jaar aan de slag kan. Of er staan 9 mensen tegenover die 10 maanden naar hun eerste baan hebben gezocht. Voor academici is de situatie nog schrijnender. Tegenover iedereen die direct na het behalen van de doctoraalbul aan de slag kan op de arbeidsmarkt, moet immers in principe iemand staan die maar liefst 40 maanden, dat wil zeggen ruim drie jaar zoekt naar de eerste volwaardige baan.

De, zelfs in het licht van de huidige arbeidsmarktsituatie, extreme hoogte van deze cijfers is voor ons aanleiding geweest de baanzoekduren nader te analyseren. Daarvoor is gebruik gemaakt van de HBOMonitor 1992 (Van de Loo, Van der Velden en Wieling, 1993). Deze enquête vindt circa 1,5 jaar na afstuderen plaats. Omdat dit onderzoek primair als doel heeft het proces van arbeidsmarktintrede van HBO'ers in kaart te brengen, bieden de cijfers een meer gedetailleerd beeld hiervan dan de CBSgegevens kunnen doen. De aangehaalde gegevens over de gemiddelde baanzoekduren zijn gebaseerd op de Enquête Beroepsbevolking (EBB) van het CBS. Dit heeft als belangrijk voordeel dat met één enquête de volledige breedte van de arbeidsmarkt wordt bereikt. Een nadeel is echter dat de enquete niet toegespitst kan zijn op het in kaart brengen van de arbeidsmarktpositie van schoolverlaters. Binnen de vragenlijst zal hier minder ruimte voor zijn, omdat deze anders al gauw te lang wordt. Daarnaast is het aantal geënqueteerde schoolverlaters in de EBB relatief klein. Terwijl de HBO-Monitor jaarlijks betrekking heeft op ruim 10.000 respondenten, zijn in de EBB gedurende twee jaar slechts ongeveer 750 recent afgestudeerden van het HBO geënquêteerd. Voor een gedetailleerde analyse van de

1. Dit onderzoek werd voor het eerst uitgevoerd in 1992. Zie voor de rapportages Berkhout en Mot (1992 en 1993) en Berkhout en Provoost (1994).

2. Zie bijvoorbeeld De Volkskrant, 19 juli 1994. 
specifieke schoolverlaters, waarbij ook nog onderscheid gemaakt moet worden naar de verschillende studierichtingen lijkt de EBB daarom onvoldoende groot te zijn. Om die reden moet de analyse van de arbeidsmarktsituatie van schoolverlaters op basis van de EBB gebaseerd worden op enkele sterk simplificerende aannames over de wijze waarop de overgang van school naar arbeidsmarkt geschiedt. Samen met het voor dit doel te beperkte karakter van de vragenlijst leiden deze aannames tot sterke vertekeningen van de gemiddelde baanzoekduur van schoolverlaters. De meeste van deze vertekeningen overschatten de baanzoekduur, zodat in totaliteit sprake is van een grote overschatting van de baanzoekduur.

De opzet van dit research memorandum is verder als volgt. Eerst wordt kort ingegaan op de definitie van baanzoekduur en hoe die op basis van enquêtegegevens kan worden bepaald. Vervolgens wordt aangegeven wat de gemiddelde baanzoekduur van HBO-afgestudeerden van het studiejaar 1990/'91 is geweest. Daarbij wordt tevens nagegaan hoe de verschillen met de resultaten van het SEO/CBSonderzoek kunnen worden verklaard. Daarna worden de verschillende studierichtingen van het HBO belicht. Vervolgens wordt kort aandacht besteed aan de baanzoekduur van academici. Het research memorandum wordt afgesloten met enkele conclusies.

\section{Bepaling van de baanzoekduur}

Het begrip baanzoekduur kan worden gedefinieerd als de tijd die verstrijkt tussen de datum waarop je begint met zoeken en de eerste relevante werkkring. Het begrip 'relevante werkkring' dient hierbij nader ingevuld te worden. In het SEO-onderzoek worden uitzendwerk, vakantiewerk, thuiswerk, seizoenswerk e.d. niet tot de relevante werkkringen gerekend. Zowel in de EBB als in de HBO-monitor is echter alleen informatie beschikbaar is over de precieze aard van het werk van de huidige baan. Dit betekent dat moet worden verondersteld dat iemand die momenteel een niet relevante werkkring bekleedt, ook tussentijds geen relevante baan heeft gehad. De gehele tijd vanaf het moment van schoolverlaten, moet dan tot de zoektijd gerekend worden. Een bijkomstig probleem is dat op basis van de EBB niet het gehele afgelopen jaar retrospectief in beeld wordt gebracht. Aangenomen wordt dan dat de tijd tussen het schoolverlaten en de begindatum van de huidige baan (mits relevant) tot zoekduur kan worden bestempeld. Het kan echter vanzelfsprekend ook zo zijn dat iemand reeds in een tweede of derde werkkring werkzaam is. Het aanmerken van deze banen als niet-relevant, zoals impliciet in het SEOonderzoek gebeurt, lijkt niet gerechtvaardigd. Juist in het begin van de carrière is er immers nogal eens sprake van baan-baan- mobiliteit van de werkenden.

Op basis van de HBO-Monitor is wel per maand bekend wat de belangrijkste activiteit sinds het moment van schoolverlaten is geweest. Om optimaal van deze gegevens gebruik te maken wordt in dit artikel voor een andere afbakening van het begrip relevante werkkring gekozen, waardoor de hierboven genoemde veronderstellingen niet meer nodig zijn. Alleen banen waarin men tenminste drie maanden werkzaam is, worden als relevant bestempeld. Korte baantjes van minder dan drie maanden worden dus genegeerd. De schoolverlaters worden gedurende deze periode als werkloos beschouwd. Het buiten beschouwing laten van niet relevante werkkringen is trouwens een typisch Europese aanpak. In de Amerikaanse visie staat het hebben van werk voorop en tellen alle banen mee (zie Summers, 1990).

Een tweede afbakening die moet worden gemaakt is het bepalen van de begindatum van het zoekproces. Studenten beginnen vaak al een baan te zoeken voordat ze klaar zijn met hun studie. Omdat 
het in kaart brengen van de gemiddelde baanzoekduren vooral als doel heeft het problematische aspect van de aansluiting tussen onderwijs en arbeidsmarkt aan te geven, wordt deze zoekduur niet meegerekend. Wel kan er een behoorlijke discrepantie bestaan tussen het moment waarop men klaar is met een studie en het formele tijdstip van afstuderen. Bij het bepalen van de zoekduur wordt als begindatum het eerstgenoemde tijdstip genomen, omdat daardoor het beste de tijd wordt gemeten die door zoeken verloren gaat.

De baanzoekduur van schoolverlaters kan nu worden bepaald door een aantal schoolverlaters te volgen en na te gaan hoeveel tijd verstrijkt tussen het eerste aanbieden op de arbeidsmarkt en de eerste werkdag in een relevante baan. Een probleem dat daarbij echter optreedt is dat er altijd schoolverlaters zullen zijn die gedurende de volgperiode nog geen baan hebben gevonden, waardoor hun feitelijke zoekduur niet kan worden vastgesteld. In de theorie van de (werkloosheids)duurmodellen ${ }^{3}$ wordt hiervoor een oplossing geformuleerd door niet naar personen maar naar tijdseenheden te kijken. lemand die na drie maanden zoeken een baan vindt is drie maal in de steekproef vertegenwoordigd. Twee 'zoekmaanden' waren niet succesvol, terwijl de laatste zoekmaand een succes opleverde. Personen met onvoltooide duren brengen alleen niet succesvolle maanden in. Door nu te veronderstellen dat iedere zoekmaand eenzelfde kans op succes heeft, kan geschat worden wanneer schoolverlaters die nog op zoek zijn naar werk een baan zullen vinden. Hiermee kan de gemiddelde zoekduur bepaald worden. Indien verder geen verklarende variabelen in het model zijn opgenomen, kan de Maximum Likelihood schatter voor de gemiddelde zoekduur $(Z)$ eenvoudig worden bepaald als:

$Z_{M L}=\frac{\text { totaal aantal gezochte maanden }}{\text { totaal aantal gevonden banen }}$

Deze schatter gaat er dus, zoals gezegd, impliciet van uit dat iedere zoekmaand evenveel kans op succes heeft. De nog te verwachten zoekduur van personen met een onvoltooide zoekduur kan daardoor worden gereconstrueerd waardoor de gemiddelde zoekduur van de gehele groep bepaald kan worden. Dit gemiddelde is daardoor gedeeltelijk opgebouwd uit waargenomen voltooide zoekduren en gedeeltelijk uit schattingen van onvoltooide zoekduren. Hoe korter de periode waarin afgestudeerders op de arbeidsmarkt worden gevolgd, hoe meer van dergelijke schattingen opgenomen worden in de gemiddelde zoekduur. Daardoor wordt de schatting van de gemiddelde baanzoekduur aanmerkelijk nauwkeuriger als studenten langer gevolgd worden op de arbeidsmarkt ${ }^{4}$.

\section{Wat kan er misgaan?}

Het toepassen van een dergelijk exponentieel duurmodel voor het bepalen van de gemiddelde baanzoekduur van schoolverlaters brengt twee problemen met zich mee. Ten eerste vinden nogal wat

3. Zie voor een overzicht van deze modellen Lancaster (1990).

4. Overigens schat het SEO een model waarin de zoekduur naast de genoten opleiding, afhangt van enkele individuele variabelen zoals geslacht, leefsituatie, etniciteit en leeftijd. Hierdoor ontstaat er een variatie in de baanvindkansen tussen personen met dezelfde opleiding. Om die reden maakt men onderscheid tussen de verwachte baanzoekduur, dat is de zoekduur die op grond van het model voor een bepaald individu wordt verwacht, en de gemiddelde baanzoekduur, waarbij het gaat om het gemiddelde over een mogelijk heterogene groep. Bij de reconstructie van de gemiddelde baanzoekduur binnen een groep spreekt men daarom over de gemiddelde verwachte zoekduur. Aangezien in ons model geen verdere verklarende variabelen zijn opgenomen, waardoor de verwachte zoekduur niet varieert binnen een opleidingscategorie, wordt hier kortweg gesproken van de gemiddelde zoekduur. 
schoolverlaters direct na schoolverlaten hun eerste relevante werkkring ${ }^{5}$. De baanzoekduur is dan gelijk aan nul. In het exponentieel duurmodel is deze mogelijkheid theoretisch uitgesloten. Als de zoekkans per tijdseenheid constant is dan moet de kans op het vinden van een baan zonder dat er tijd verstrijkt gelijk zijn aan nul. Daarom wordt in dit artikel een aangepast model gehanteerd waarbij iedere afstudeerder een kans heeft om onmiddellijk werk te vinden. Alleen voor degenen die niet meteen een baan hebben wordt het exponentiële duurmodel geschat.

Figuur 1

Invloed van meetfout op geschatte baanzoekduur

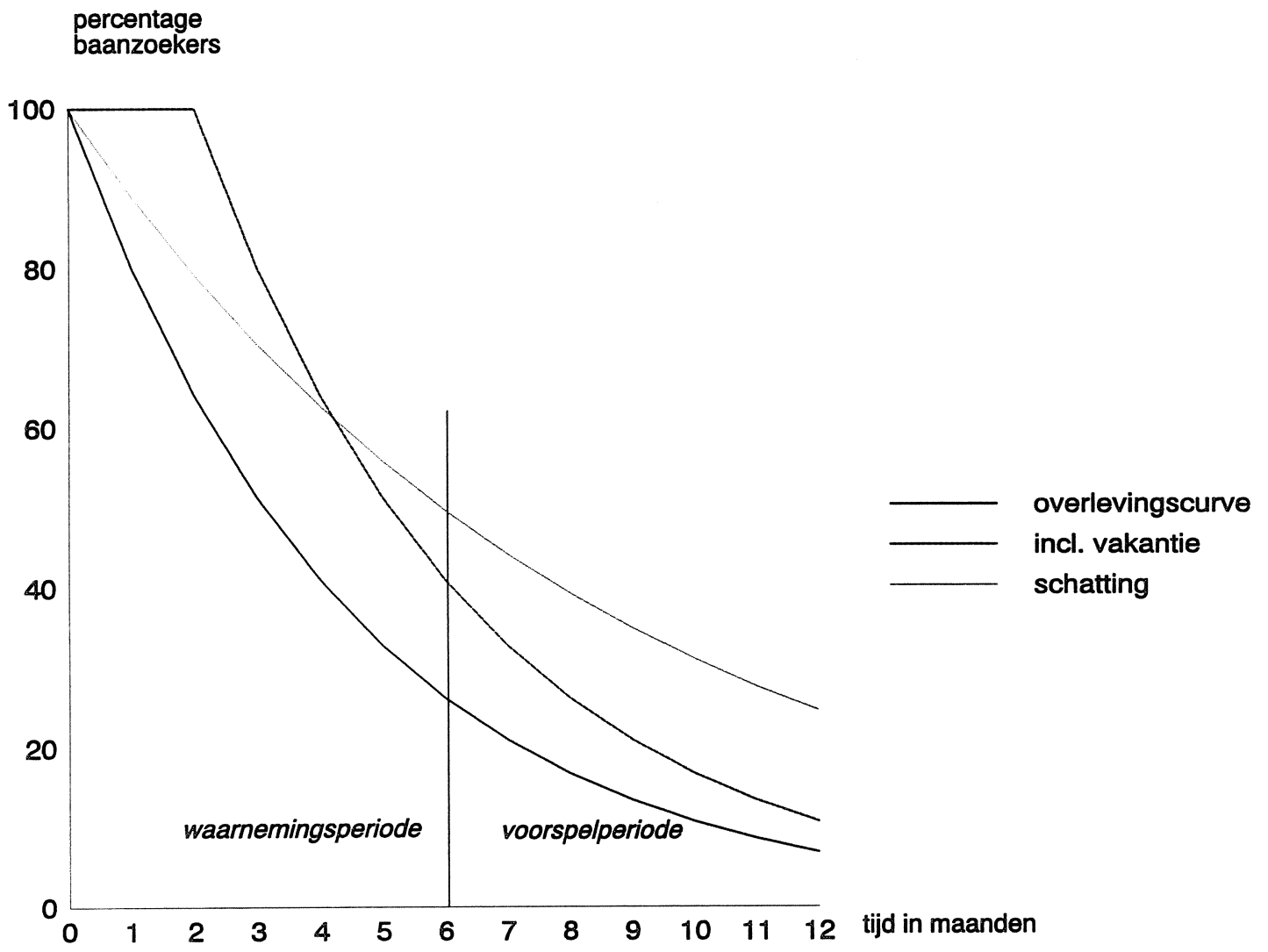

Een tweede complicatie wordt gevormd door de veronderstelling dat de baanvindkans iedere maand gelijk is. Stel een schoolverlater besluit om na het behalen van zijn diploma twee maanden op vakantie te gaan. Als deze twee maanden ten onrechte worden meegerekend als zoekduur wordt een dubbele fout gemaakt. Niet alleen wordt de zoekduur ten onrechte met twee maanden verlengd, maar ook wordt de succeskans hierdoor verlaagd. Als de schoolverlater zes maanden wordt gevolgd, veronderstelt het model dat de periode na deze zes maanden even succesvol zal zijn. Impliciet wordt daardoor aangenomen dat ook in de toekomst van iedere zes maanden twee maanden vakantie wordt genomen. Figuur 1 laat zien dat door deze meetfout het aantal nog werkzoekende schoolverlaters wordt overschat en dat de snelheid waarmee deze restgroep werk vindt te laag wordt geschat. Twee maanden vakantie worden daardoor geregistreerd als meer dan twee maanden extra zoekduur. Vooral als, zoals het geval is bij de EBB, slechts een relatief korte periode van het zoekproces wordt geregistreerd heeft dit ernstige gevol-

5. Uit de gegevens uit de HBO-Monitor 1992 blijkt dat voor vrijwel alle opleidingstypen het percentage schoolverlaters dat onmiddellijk werk vindt, boven de $50 \%$ ligt. 
gen voor de schattingsresultaten.

\section{Resultaten}

Zoals reeds is aangegeven, kan voor het bepalen van de gemiddelde zoekduur van HBO-afgestudeerden gebruik worden gemaakt van de gegevens van de HBO-Monitor 1992. In deze enquête onder de afgestudeerden van het studiejaar 1990/'91 wordt gevraagd wat per maand de belangrijkste activiteit van de respondent is geweest, vanaf september 1990 tot november/december 1992. Hiermee kan de baanzoekduur gedurende deze periode perfect in kaart worden gebracht. Deze gegevens kunnen het beste vergeleken worden met de resultaten van het SEO/CBS-onderzoek van 1993 (zie Arbeidsvoorziening, 1993).

Wanneer met het aangepaste exponentiële model de baanzoekduur van recent HBO-afgestudeerden wordt bepaald, dan blijkt deze gemiddeld 1,9 maanden te bedragen. Dit is derhalve beduidend lager dan de resultaten die door het SEO worden verkregen. De vraag is nu waardoor dit verschil wordt veroorzaakt. Tabel 1 geeft een overzicht van gemiddelde baanzoekduren van HBO'ers, berekend volgens vijf varianten. Daarmee wordt een beeld verkregen van het effect van de verschillende aannamen die in het baanzoekduurmodel worden gemaakt.

Tabel 1

Gemiddelde baanzoekduur van HBO-afgestudeerden 1990/91: vijf varianten

1. Aangepast model, zoektijd tot eerste relevante baan, overige activiteiten niet meegerekend als zoekduur

2. Standaard model, zoektijd tot eerste relevante baan, overige activiteiten niet meegerekend als zoekduur

3. Standaard model, zoektijd tot eerste relevante baan, overige activiteiten wel meegerekend als zoekduur

4. Standaard model, zoektijd tot huidige relevante baan, overige activiteiten wel meegerekend als zoekduur

Bij het SEO-model wordt geen aangepaste versie van het zoekmodel gehanteerd, omdat in de EBB vrijwel niemand een baanzoekduur van 0 maanden heeft. Door de wijze van registreren wordt vrijwel iedere zoekduur op tenminste een maand gezet. De gemiddelde baanzoekduur wordt daardoor met 0,8 maanden overschat: in plaats van 1,9 maanden bedraagt de gemeten zoekduur 2,7 maanden. Een tweede aanpassing die aan het model kan worden gemaakt, betreft de definitie van de hoeveelheid tijd die men besteed aan zoeken. Wij gaan er van uit dat de maanden die men aan andere activiteiten besteedt (bijvoorbeeld vakantie) niet tot de baanzoekduur moeten worden gerekend. Als deze tijd echter wel volledig tot werkzoeken wordt gerekend, dan blijkt de gemiddelde baanzoekduur van HBO'ers 4,1 maanden te zijn. De gemeten baanzoekduur neemt door deze definitiewijziging derhalve met 1,4 maanden toe. 
Vervolgens kunnen de verschillen in de enquête-opzet tussen de EBB en de HBO-Monitor het verschil in gemeten baanzoekduur verklaren. Zoals hierboven reeds is opgemerkt, kan met behulp van de EBB alleen de begindatum van de huidige baan worden vastgesteld, zodat moet worden aangenomen dat eventuele tussentijdse banen als niet relevante werkkringen moeten worden aangemerkt. In variant 4 is op basis van de HBO-Monitor uitgerekend wat het effect van deze aanname is. Het blijkt dat daardoor de gemeten baanzoektijd maar liefst $60 \%$ hoger ligt, namelijk 6,6 maanden in plaats van 4,1 maanden. Dit is ook niet zo vreemd wanneer wordt bedacht dat ongeveer de helft van de HBO'ers in het eerste anderhalf jaar na afstuderen meer dan één functie heeft vervuld en eveneens ongeveer de helft in meer dan één organisatie heeft gewerkt (zie Van de Loo, Van der Velden en Wieling, 1993).

Een tweede 'EBB-effect' heeft betrekking op het feit dat deze enquête op een willekeurig moment in het eerste jaar na afstuderen valt. Dit houdt in dat gemiddeld genomen van één twaalfde deel van de schoolverlaters informatie over twaalf maanden na schoolverlaten beschikbaar is, van één twaalfde deel informatie over elf maanden enz. Gemiddeld genomen registreert de EBB daardoor slechts de eerste zes maanden op de arbeidsmarkt. Deze enquête-opzet kan eenvoudig op basis van de HBO-Monitorgegevens worden gesimuleerd. De gemiddelde zoektijd blijkt dan niet op 6,6 maanden uit te komen, maar op 5,4 inaanden. Deze verlaging van de waargenomen zoektijd kan worden verklaard, doordat juist in de eerste maanden na afstuderen de kans op het vinden van een baan relatief hoog zal zijn. In een exponentieel model met constante baanvindkans zal bij een oververtegenwoordiging van deze korte duren de geschatte uittreevoet hoger liggen en de gemiddelde baanzoekduur dus lager. Aan de andere kant zullen er in dat geval meer onvoltooide duren in de steekproef zitten waardoor het effect van meetfouten groter wordt. Blijkbaar weegt dit effect niet op tegen de oververtegenwoordiging van korte duren.

Opvallend genoeg komt de geschatte gemiddelde baanzoekduur van 5,4 maanden exact overeen met de 'normobservatie' voor HBO-schoolverlaters in het SEO-onderzoek voor de vergelijkbare periode. De normobservatie van het SEO/CBS kan overigens niet precies vergeleken worden met de gemiddelde zoekduur uit de HBO-Monitor. De normobservatie is de verwachte zoekduur voor een persoon met de norm-eigenschappen, terwijl het gemiddelde gebaseerd is op de verdeling van de eigenschappen in de steekproef. De overeenkomst wijst er overigens wel op dat het hier geconstateerde verschil met onze schatting van de gemiddelde baanzoekduur van HBO'ers (1,9 maanden) goed door de vier hier beschreven effecten kan worden verklaard. Er zijn echter nog enkele kleine discrepanties die het verschil in waargenomen zoekduur nog groter zullen maken. Een voorbeeld hiervan betreft een opeenvolgende van kortdurige contracten waarbij volgens de SEO/CBS-methode alleen de laatste baan wordt meegenomen en de selectie op relevante werkkring die het CBS doorvoert. Deze verschillen kunnen echter niet precies worden gesimuleerd.

\section{Verschillen tussen studierichtingen}

Tot nu toe is alleen gekeken naar de gemiddelde baanzoekduur van de gehele groep recent afgestudeerden van het HBO. Het is echter interessant om juist de verschillen tussen de diverse studierichtingen te belichten. In tabel 2 wordt aangegeven hoe lang de gemiddelde zoekduur van HBO'ers is, verbijzonderd naar een aantal opleidingstypen. Daarbij is zowel de zoekduur volgens variant 1 als die volgens variant 5 bepaald.

Het blijkt dat voor alle studierichtingen de baanzoekduur volgens variant 5 met een factor 2 tot 4 wordt 
overschat. Bij de richting haven en vervoer is het verschil tussen beide varianten relatief gezien het grootst. Bij de richting technische bedrijfskunde bestaat er eveneens een grote discrepantie tussen beide varianten. Ook bij de richting kunst treedt een opvallend verschil op. Terwijl volgens onze methode de (gemiddelde) baanzoekduur voor afgestudeerden in deze richting op 6,5 maanden wordt geschat, is dit volgens variant 5 maar liefst bijna 14 maanden.

Tabel 2

Gemiddelde baanzoekduur van HBO-afgestudeerden 1990/91 verbijzonderd naar opleidingsrichting

\begin{tabular}{lccc}
\hline Opleidingsrichting & $\begin{array}{l}\text { baanzoekduur } \\
\text { variant 1 }\end{array}$ & $\begin{array}{l}\text { baanzoekduur } \\
\text { variant 5 }\end{array}$ & $\begin{array}{l}\text { aantal } \\
\text { waarnemingen }\end{array}$ \\
\hline Onderwijs & 2,9 & 6,1 & 753 \\
Technisch laboratorium & 1,2 & 4,4 & 138 \\
Technisch & 1,9 & 5,8 & 696 \\
Haven en vervoer & 0,6 & 3,8 & 92 \\
Medisch laboratorium & 1,3 & 3,9 & 1213 \\
Verpleging en paramedisch & 1,3 & 4,4 & 1119 \\
Economisch-administratief & 1,4 & 5,3 & 125 \\
Technische bedrijfskunde & 1,3 & 5,4 & 639 \\
Bestuurlijk & 1,6 & 5,5 & 72 \\
Sociaal-cultureel & 2,1 & 5,6 & 171 \\
Verzorging & 1,5 & 5,2 & 218 \\
Horeca & 1,4 & 4,5 & \\
Kunst & 6,5 & 13,9 & \\
\end{tabular}

In het algemeen kan worden geconcludeerd dat voor de meeste studierichtingen de gemiddelde baanzoekduur tussen de één en twee maanden ligt. Schoolverlaters van het HBO haven en vervoer vinden relatief snel een baan. Degenen die in de richting kunst zijn afgestudeerd hebben daarentegen relatief veel tijd nodig om een relevante werkkring te vinden. Ook de afgestudeerden van de lerarenopleiding en het sociaal-cultureel onderwijs hebben een relatief lange zoektijd. Overigens is er wel sprake van een duidelijke tweespalt in de verdeling van de baanvinders. Aan de ene kant is er een redelijk omvangrijke groep schoolverlaters $(55 \%)$ die meteen een baan vindt. Aan de andere kant is er echter ook een groot aantal schoolverlaters dat redelijk lang op zoek is naar een relevante werkkring. De gemiddelde baanzoekduur van de resterende $45 \%$ van de schoolverlaters, die niet reeds bij afstuderen werk hadden, bedraagt daardoor geen 1,9 maar 4,1 maanden.

\section{De baanzoekduur van academici}

Wellicht de opvallendste conclusie van het meest recente SEO/CBS-onderzoek (Berkhout en Provoost, 1994 ) is dat de gemiddelde baanzoekduur van academici maar liefst 20 maanden bedraagt. Helaas zijn er geen met de HBO-Monitor vergelijkbare gegevens beschikbaar voor pas afgestudeerde academici. Op grond van de hierboven gepresenteerde bevindingen voor HBO'ers lijkt het echter aannemelijk dat, wanneer enige aanpassingen in model, veronderstellingen en wijze van enquêteren zouden worden aangebracht, de schatting van de gemiddelde baanzoekduur van de afgestudeerden van het WO aanzienlijk lager is. 
Toch lijkt het verschil in aanpak tussen variant 1 en variant 5 de relatief hoge baanzoekduur voor academici niet volledig te kunnen verklaren. $\mathrm{Er}$ speelt dan ook een additioneel probleem, te weten dat de afstudeermaand van academici op basis van de EBB-gegevens niet bekend is. In het SEO/CBSmodel wordt daarom verondersteld dat iedereen op 1 januari is afgestudeerd. Dit betekent dat, er van uitgaande dat er gelijke spreiding van de afstudeerdata over de maanden is, gemiddeld de afstudeerdatum een half jaar te vroeg wordt ingeschat. Deze vertekening wordt daarom achteraf gecorrigeerd door 6 maanden van de geschatte zoekduur af te trekken. Overigens moet de lezer zelf deze 6 maanden nog in mindering brengen op de in het rapport gepresenteerde getallen.

Omdat een meetfout van de gerealiseerde zoekduur echter meer dan evenredig doorwerkt in de voorspelde zoekduur leidt deze werkwijze tot een forse overschatting van de gemiddelde baanzoekduur, zoals blijkt uit de resultaten van eenvoudige simulatie die zijn weergegeven in figuur 2 . Bij een feitelijke zoekduur van 1 maand treedt er nog nauwelijks vertekening op. Wanneer echter de baanzoekduur in werkelijkheid 2 maanden bedraagt, dan geven de modeluitkomsten 2,6 maanden aan; een vertekening van $32 \%$. Deze vertekeningsfactor neemt verder toe tot circa $100 \%$ naarmate de zoekduur langer is. Bij een gemeten zoekduur van 20 maanden blijkt de feitelijke zoekduur ongeveer 11 maanden te zijn. Gecombineerd met de hierboven aangegeven verschillen tussen de modelvarianten, werpt dit een heel ander licht op de baanzoekduren van academici.

\section{Figuur 2}

Vertekening van de geschatte zoekduur van academici: simulatieresultaten

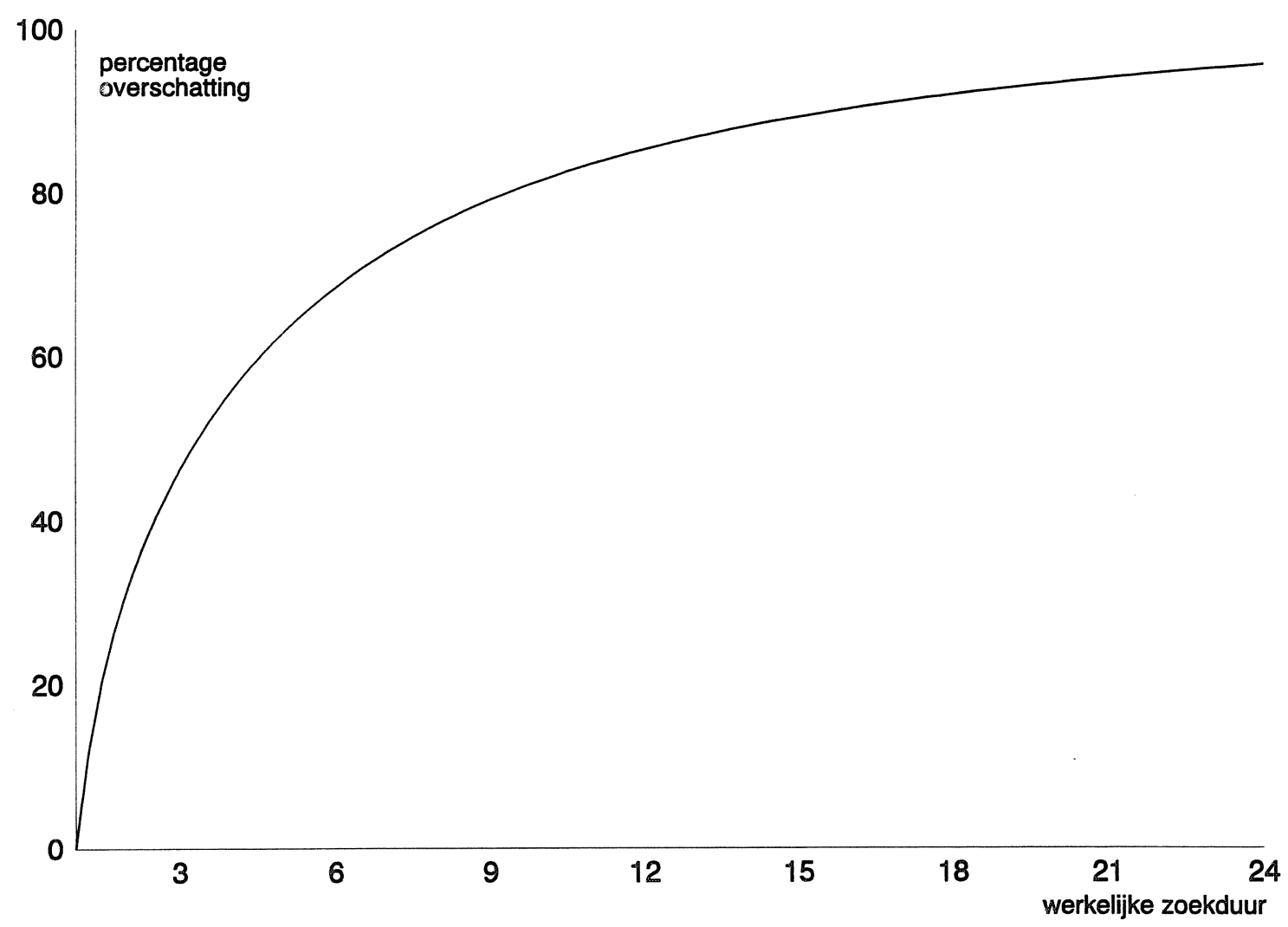




\section{Besluit}

Het momenteel heersende beeld dat schoolverlaters erg veel tijd nodig hebben om een relevante baan te vinden is in dit artikel genuanceerd. Met enkele kleine aanpassingen in model en definities wordt een geheel ander beeld van de directe aansluiting tussen onderwijs en arbeidsmarkt verkregen. Aan de precieze waarden van de gemiddelde baanzoekduur van schoolverlaters, zoals die in de media zijn gepresenteerd, moet daarom ons inziens nauwelijks betekenis worden toegekend. De resultaten kunnen hoogstens indicatief zijn voor de verschillen in de mate waarin schoolverlaters van de diverse opleidingen problemen ondervinden bij het toetreden tot de arbeidsmarkt.

Dit research memorandum heeft bovendien aangetoond dat analyses met betrekking tot het intredeproces van schoolverlaters op de arbeidsmarkt beter met specifiek voor dit doel verzamelde gegevens kunnen worden verricht. De EBB is gezien haar doelstelling in haar vraagstelling niet voldoende toegespitst om de positie van schoolverlaters in kaart te brengen. Met behulp van de HBO-Monitor-gegevens, waarvan in dit paper gebruik is gemaakt, kan van maand tot maand de belangrijkste activiteit van de recent afgestudeerden worden bekeken.

De eerste arbeidsmarktervaringen van HBO'ers wijken sterk af van het leerboekvoorbeeld dat bestaat uit studeren, werk zoeken, werken. In werkelijkheid blijken schoolverlaters veelvuldig te veranderen van baan en wisselen zij werk of werk zoeken af met andere activiteiten zoals vakantie en verdere scholing. Het is daardoor interessant om na te gaan hoe het intredeproces van schoolverlaters op de arbeidsmarkt verloopt. In welke banen komen zij initieel terecht? En vooral ook: hoe structureel is een eventuele slechte aansluiting van de eerste baan op het gevolgde onderwijs? Blijft men in dergelijke banen hangen of is er sprake van een vrij snelle doorstroom van jongeren naar beroepen en functies die beter bij hun opleidingsachtergrond passen. Vooral deze dynamische aspecten van de aansluiting tussen onderwijs en arbeidsmarkt zijn moeilijk in één indicator te ondervangen. Het is daarom beter om het intredeproces van jongeren op de arbeidsmarkt goed te 'monitoren' met op dit doel toegesneden instrumenten. Op die manier kan de daadwerkelijke mismatch tussen onderwijs en arbeidsmarkt in kaart worden gebracht.

\section{Literatuur}

Arbeidsvoorziening (1993), Schoolverlatersbrief 1993, Rijswijk.

Berkhout, P.H.G., E.S. Mot (1992), De arbeidsmarktrelevantie van opleidingen, OAV-rapport 92-08, Rijswijk.

Berkhout P.H.G., E.S. Mot (1993), De arbeidsmarktrelevantie van opleidingen: vervolgstudie, OAV-rapport 93-07, Rijswijk.

Berkhout P.H.G., J.C. Provoost (1994), Schoolverlaters op zoek naar een baan: een duuranalyse, SEO-rapport nr. 339, Amsterdam.

Lancaster, T. (1990), The Econometric Analysis of Transition Data, Cambridge University Press, Cambridge.

Loo, P.J.E. van de, R.K.W. van der Velden, M.H. Wieling (1993), De arbeidsmarktpositie van afgestudeerden van het hoger beroepsonderwijs, HBO-Monitor 1992, Voorlichtingsdienst HBO-Raad, Den Haag.

Summers, L.H. (1990), Understanding unemployment, MIT Press, Cambridge (Mass.). 